\title{
KOMPARASI KINERJA KEUANGAN SEBELUM DAN SESUDAH MERGER DAN AKUISISI PADA PERUSAHAAN PENGAKUISISI DI BEI
}

\author{
Neneng Sri Suprihatin \\ Neneng.sri@unsera.ac.id \\ Akuntansi, Universitas Serang Raya
}

\begin{abstract}
Abstrak
Riset ini dilakukan untuk meneliti secara empiris mengenai perbedaan kinerja keuangan antara kondisi sebelum dan sesudah proses merger dan akuisisi yang dalam prosesnya digunakan beberapa variable rasio keuangan diantaranya Current Ratio (CR), Debt to Asset Ratio (DAR), Total Asset Turnover (TATO), Net Profit Margin (NPM), Return on Asset (ROA), Return on Equity (ROE), Earning Per Share (EPS), Price Earning Ratio (PER ). Riset ini merupakan penelitian kuantitatif dengan menggunakan desain penelitian yang merupakan penelitian komparatif. Data penelitian bersumber dari BEI yang mengambil data entitas perusahaan pada tahun 2015 telah mengalami proses merger serta akuisisi dan serta tahun ke empat setelahnya juga dilakukan proser merger serta akuisisi, sehingga periode riset ini adalah pada tahun 2013-2019. Selanjutnya pengambilan sampel dari populasi yang ada menggunakan tenik purposive sampling dengan menggunakan kriteria tertentu dari total 34 perusahan didapat 10 perusahaan yang memenuhi kriteria yang diambil sabagai sampel dengan periode pengamatan 7 tahun maka didapat total sampling data 70 data. Metode riset ini menggunakan uji beda dengan hasil dari riset diantaranya terdapat perbedaan kinerja keuangan antara kondisi pada saat sebelum dan setelah proses merger dengan beberapa variasi tahun dengan menggunakan variable Current Ratio (CR), Debt to Asset Ratio (DAR), Total Asset Turnover (TATO), Return on Asset (ROA), Return on Equity (ROE) tetapi ada juga yang tidak terdapat kinerja keuangan yang berbeda antara sebelum dan sesudah merger dengan menggunakan variable net profit margin (NPM), Earning per share (EPS ) dan Price Earning Ratio (PER).
\end{abstract}

Kata Kunci : Kinerja keuangan, Merger dan Akuisisi

\section{COMPARATIVE FINANCIAL PERFORMANCE BEFORE AND AFTER MERGERS AND ACQUISITIONS OF ACQUIRING COMPANIES ON IDX}

\begin{abstract}
This research was conducted to empirically examine the differences in financial performance between conditions before and after the merger and acquisition process, which in the method used several financial ratio variables including Current Ratio (CR), Debt to Asset Ratio (DAR), Total Asset Turnover (TATO), Net Profit Margin (NPM), Return on Assets (ROA), Return on Equity (ROE), Earning Per Share (EPS), Price Earning Ratio $(P E R)$. This research is quantitative research using a comparative research design. The research data is sourced from the IDX, which takes information on corporate entities in 2015 which have undergone a merger and acquisition process, and in the fourth year after that, mergers and acquisitions have also been carried out, so the research period is 2013-
\end{abstract}


2019. Furthermore, taking samples from the existing population using purposive sampling technique using specific criteria, from 34 companies, ten companies that meet the measures were taken as samples with an observation period of 7 years, so data obtained a total sampling of 70 data. This research method uses a different test with the results of the research including there are differences in financial performance between conditions before and after the merger process with several variations in years using the Current Ratio (CR) variable, Debt to Asset Ratio (DAR), Total Asset Turnover (TATO). ), Return on Assets (ROA), Return on Equity (ROE), but there is also no other financial performance between before and after the merger using the variable net profit margin (NPM), Earning per share (EPS) and Price Earning Ratio (PER).

\section{Keywords: Financial Performance, Mergers and Acquisitions}

\section{PENDAHULUAN}

Dengan berkembangnya dunia usaha yang didukung oleh majunya teknologi informasi dan ditambah era perdagangan pasar bebas menjadikan persaingan perusahaan semakin kompetitif. Hal ini membuat perusahaan harus senantiasa menemukan cara jitu agar perusahaan mampu bertahan dalam persaingan dan berkembang. Menurut Ketua Asosiasi Pengusaha Indonesia (Apindo) Sanny Iskandar dalam Immanuel F (2020), cara yang digunakan oleh perusahaan dalam menghadapi kompetisi antar perusahan agar perusahaan mampu tetap bertahan dan juga bisa mengalami perkembangan adalah dengan menjalankan proses merger dan akuisisi.Aksi merger dilakukan oleh perusahaan agar bisa bertahan, sementara transaksi akuisisi dilakukan untuk memperkuat atau mengembangkan bisnisnya. Merger dan akuisisi merupakan sebuah upaya yang dilakukan perusahaan dalam melakuan percepatan pertumbuhan entitas atau perusahaan beberapa diantaranya adalah dengan melakukan ekspansi pasar baru untuk launching produk terbaru. Dalam pelaksanaannya proses fusi perusahaan dengan melakukan merger dan akuisi ditujukan atas harapan agar tercipta kesatuan usaha yang kuat dan besar, karena nilai perusahaan lebih besar setelah dilakukan penggabungan dari pada nilai masing-masing perusahan tersebut. Proses merger dimulai pada saat kedua entitas (perusahaan) dengan cara menggabungkan aset (aktiva) perusahaan dengan kewajiban perusahaan. Owner (pemilik) perusahaan hasil penggabungan menjadi pemilik usaha baru, dalam proses merger, sebagai contoh perusahaan "AIUEO" merger dengan salah satu perusahaan "BABIBU" maka perusahaan yang eksis hanyalah salah satu perusahaan bertahan sebagai pemilik perusahaan gabungan baru sementara perusahaan (entitas) lainnya akan berhenti beroperasi atau menghilang dengan cara likuidasi atau pun tidak.

Akuisisi merupakan proses pengambilalihan sebagian atau seluruh kepemilikan entitas yang dilakukan dengan cara membeli kepemilikan saham yang ada pada perusahaan yang akan diakuisisi. Selanjutnya dalam Kusumaningtyas \& Handayani (2018) menjelaskan bahwa proses akuisisi dapat diakukan dengan memiliki mayoritas saham dalam suatu perusahaan atau dengan menguasai kepemilikan aset yang ada pada perusahaan.

Perbankan Indonesia telah beberapa kali mengalami krisis keuangan (moneter) dimulai pada tahun 1998 yang mengguncang perekonomian Indonesia pada saat itu yang diakibatkan penarikan dolar besar-besaran akibat jatuh temponya hutang swasta dan negara yang mengakibatkan rush sehingga harga tukar rupiah anjlok drastic dari mata uang dolar dan perbankan juga mengalami dampak akibat krisis. Krisis moneter pun terjadi pada tahun 2008 krisis ini dikenal dengan krisis subprime mortage yang merupakan surat kredit yang dapat diperjualbelikan oleh pemneri mortage kepada pihak lain dengan nilai suku bunga tertentu (sudarsono, 2009). pada saat masa krisis merger dan akuisisi seringkali dilakukan perusahaan dalam sebagai salah satu cara alternatif guna bertahan di masa-masa krisis ekonomi sebagai 
contoh tahun 1998 krisis moneter dan keuangan menghantam Indonesia yang berdampak pada banyaknya perusahaan yang tumbang hingga bangkrut sehingga banyak perusahaaan besar yang melakukan merger dan akuisisi (Gustina I, 2017). Selain bertujuan untuk bertahan (survive) di era persaingan usaha yang semakin kompetitif ada juga beberapa hal yang menjadi penyebab perusahaan mengambil Langkah merger dan akusisi diantaranya adalah sebagai wujud langkah strategi perusahaan untuk saling melengkapi antar perusahaan, guna menjawab peluang strategi atas perkembangan pasar, juga menambah daya saing perusahaan secara langsung dengan meningkatkan tingkat efektivitas dan efisien dalam harga yang kompetitif. Selain beberapa keuntungan yang sudah dijelaskan diatas proses merger dan akuisisi juga memiliki dampak negatif bagi perusahaan yang mengalami proses merger dan akuisisi salah satu yang utama adalah kegiatan proses merger dan akusisi memerlukan biaya yang besar dan terkadang tidak hasil yang diperoleh tidak sesuai dengan harapan. Selain itu proses merger dan akuisisi juga berdampak buruk bagi keuangan perusahaan yang melakukan merger dan akuisisi jika dalam proses strukturisasi keuangan dilakukan baik secara tunai maupun kredit. Permasalahan selanjutnya yang muncul dari proses merger dan akuisisi adalah budaya perusahaan (culture corporation) yang berdampak bagi karyawan dan budaya kerjanya. Proses merger dan akuisisi juga berdampak munculnya resiko dalam hal proses alih dan tanggungjawab atas kewajiban yang muncul dari perusahaan yang terlibat merger dan akuisisi (Sumarah D \& Priantinah D 2018). Dari uraian kasus-kasus yang terjadi maka penulis tertarik untuk menelaah lebih lanjut mengenai merger dan akuisisi yang terjadi di Indonesia dengan memperhatikan kinerja keuangan yang terjadi di beberapa sektor perusahaan yang ada di Bursa Efek Indonesia (BEI) tahun 2013-2019 dengan kondisi sebelum dan setelah perusahaan melakukan proses merger dan akuisisi.

\section{Merger dan Akuisisi}

\section{TINJAUAN PUSTAKA}

Proses merger menjadi pilihan yang diambil entitas perusahaan guna memperbesar dan membuat perusahaan lebih berkembang agar dapat menguasai pasar dengan melakukan penggabungan secara ekonomi beberapa entitas usaha menjadi satu usaha ekonomi baru (Gustina I, 2017). Dalam Liaman dan Hatane (2017) menjelaskan bahwa kegiatan menggabungkan beberapa unit entitas atau perusahaan menjadi sebuah unit usaha baru atau unit usaha yang telah ada secara badan hukum sementara unit usaha yang digabungkan tadi mengalami proses shutdown (berhenti). Sementara akuisi dapat dijelaskan sebagai kegiatan ambil alih kepemilikan usaha suatu entitas atau lebih dengan menguasai saham yang ada diperusahaan atau menguasai aset yang ada diperusahaan yang diakuisi. Penjelasan lainnya tentang akuisisi menurut pedoman standar akuntansi nomor 22 menjelaskan bahwa kegiatan penggabungan usaha berakibat kepada pengalihan kekuasaan perusahaan yang telah diambil. Perusahaan yang melakukan akuisisi atas perusahaan lain biasanya memiliki skala usaha lebih besar jika dibandingkan dengan perusahaan yang diakuisisi.

\section{Analisis Kinerja Keuangan}

Dalam penelitian yang dilakukan Sudana (2015) dijelaskan bahwa analisis kinerja dengan rasio keuangan digunakan sebagai indikator guna melihat seberapa besar kekuatan dan titik lemah suatu perusahaan atau entitas. Data dari analisis kinerja dengan rasio keuangan digunakan guna mengevaluasi capaian kinerja yang dilakukan oleh manajmen perusahan dan sebagai bahan masukan dalam pengembangan serta penyusunan rencana (planning) dimasa mendatang. Ada banyak cara yang dapat digunakan agar mendapatkan data yang diperlukan dari laporan keuangan perusahaan (entitas), pengukuran keuangan (analisis keuangan) dijadikan alternatif cara dalam mengevaluasi kinerja perusahaan. Proses penilaian kinerja perusahaan dapat dilakukan dengan menggunakan cara menilai atau mengevaluasi laporan 
keungan, evaluasi ini dapat dilakukan dengan menggunakan standar akuntansi sebagai acuan pengukuran dalam melihat keuntungan operasi, keuntungan usaha bersih dan cash flow dari operasional usaha entitas perusahaan.

Penggunaan penilaian rasio keuangan dipakai guna melakukan evaluasi dari kinerja keuangan entitas atau perusahaan serta melakukan komparasi dari berbagai macam pos yang disajikan dalam laporan keuangan guna melihat keadaan keuangan perusahaan dan hasil yang dicapai atas jalannya operasional perusahaan. Data informasi dari hasil Analisa keuangan dijadikan dasar bagi peneliti untuk menggambarkan kondisi dan keadaan keuangan perusahaan. Ada beberapa rasio keuangan yang dijadikan sebagai alat ukur dalam riset ini diantaranya:

1. Rasio Likuiditas, rasio ini dipakai untuk menggambarkan potensi perusahaan atau entitas untuk melunasi kewajiban lancarnya.

Dalam penelitian yang dilakukan Moctar \& Xiaofang tahun 2014, diuraikan bahwa rasio likuiditas (current ratio) merupakan salah satu cara penilaian rasio keuangan dalam melihat potensi perusahan guna memenuhi kewajiban lancarnya dengan menggunakan aset lancer yang terdapat dalam perusahaan. Rasio ini bertujuan menggambarkan potensi perusaahn dalam menjamin kewajiban lancar dengan menggunakan asset lancar yang dikuasai oleh perusahaan. Adapun rumus perhitunganya adalah:

$$
\text { Current Ratio }=\frac{\text { Aset Lancar }}{\text { Hutang Lancar }}
$$

2. Rasio Leverage, rasio pengukuran ini digunakan untuk menilai kebutuhan keuangan suatu entitas perusahaan yang dibiayai dengan dana yang berasal dari pinjaman. Dalam pengukurannya rasio leverage dapat menggunakan ukuran debt ratio dengan cara membandingkan total hutang yang dimiliki perusahaan dengan total aktiva yang dikuasai oleh entitas. Berikut ini adalah rumus untuk menghitung debt ratio: (sudana, 2015).

$$
\text { Debt Ratio }=\frac{\text { Total Hutang }}{\text { Total Asset }}
$$

3. Rasio Aktivitas, adalah suatu penilaian keuangan yang dirujuk dengan tujuan mengetahui seberapa efektifnya perusahaan dalam mengelola dana yang ada. Total Assets Turn Over (TATO) digunakan periset untuk mengetahui berapa rasio aktivitas perusahaan.

Total assets turnover (TATO) merupakan suatu cara pengukuran efisiensi perusahaan dalam menggunakan asset yang terdapat di perusahaan guna mendapatkan tingkat jumlah penjualan tertentu. Informasi yang diperoleh dari pengukuran ini adalah perbandingan penggunaan kekayaan perusahaan (aktiva) dalam memperoleh jumlah penjualan bersih. Rasio ini bertujuan guna melihat sebarapa efisien aktiva yang digunakan perusahaan guna memperoleh penghasilan. Rumusnya adalah sebagai berikut: (Tarigan, 2018).

$$
\text { TATO }=\frac{\text { Penjualan Bersih }}{\text { Total Aktiva }}
$$

4. Rasio Profitabilitas, rasio ini diigunakan guna meliihat tingkat efektivitas operasional manajemen perusahaan dengan menggunakan indikator imbalan hasil dari investasi melalui aktivitas penjualan perusahaan. ada beberapa macam rasio profitabilitas yang dipakai peneliti yakni:

- Net profit margin (NPM) atau sering dikenal margin laba bersih adalah sebuah penilaian keuangan yang menggambarkan tingkat persentase laba bersih (net profit) yang diperoleh dari setiap penjualan. 


$$
N P M=\frac{\text { Laba Bersih }}{\text { Penjualan Bersih }}
$$

- Return on Assets (ROA) merupakan suatu cara pengukuran pengembalian yang dijamikan dengan aset milik entitas usaha, rasio ini pun dipakai guna mengetahui potensi perusahaan/entitas usaha dalam membiayai aktiva berupa asset yang dikuasai entitas atau perusahaan.

$$
R O A=\frac{\text { Laba Bersih }}{\text { Total Aset }}
$$

- Return on Equity (ROE) yaitu pengukuran keuangan guna menentukan besaran laba (keuntungan) bagi pemilik saham (investor) perusahaan. Apabila tingkat ROE suatu perusahaan meningkat maka dapat diartikan jumlah penerimaan entitas atau perusahaan atas potensi penerimaan investasi baik dan manajemen biaya juga berjalan efektif.

$$
R O E=\frac{\text { Laba Bersih }}{\text { Equitas Pemegang Saham }}
$$

5. Rasio Pasar merupakan suatu rasio pengukuran guna melihat nilai perusahaan dimasa depan dengan membandingkan nilai perusahaan dimasa lampau. Entitas usaha (perusahaan) yang kepemilikan sahamnya di pasar modal telah dijual maka jenis pengukuran ini lebih mudah dilakukan. Dalam riset ini peneliti menggunakan beberapa jenis rasio pasar, antara lain:

- Earning Per Share (EPS) adalah suatu cara yang digunakan perusahaan untuk menilai tingkat keberhasilan perusahaan guna memberikan keuntungan bagi para investor.

$$
E P S=\frac{\text { Laba Bersih Setelah Pajak }}{\text { Jumlah Saham biasa yang beredar }}
$$

- Price Earnings Ratio (PER) yaitu salah satu ukuran fianansil yang bertujuan sebagai pembanding antara harga pasar saham per lembar saham dengan jumlah keuntungan (laba) per lembar saham. Proce Earnings Ratio (PER) bertujuan guna melihat tingkat pertumbuhan perusahaan

$$
P E R=\frac{\text { Harga Per Saham }}{\text { Laba per lembar saham }}
$$




\section{Kerangka Pemikiran}

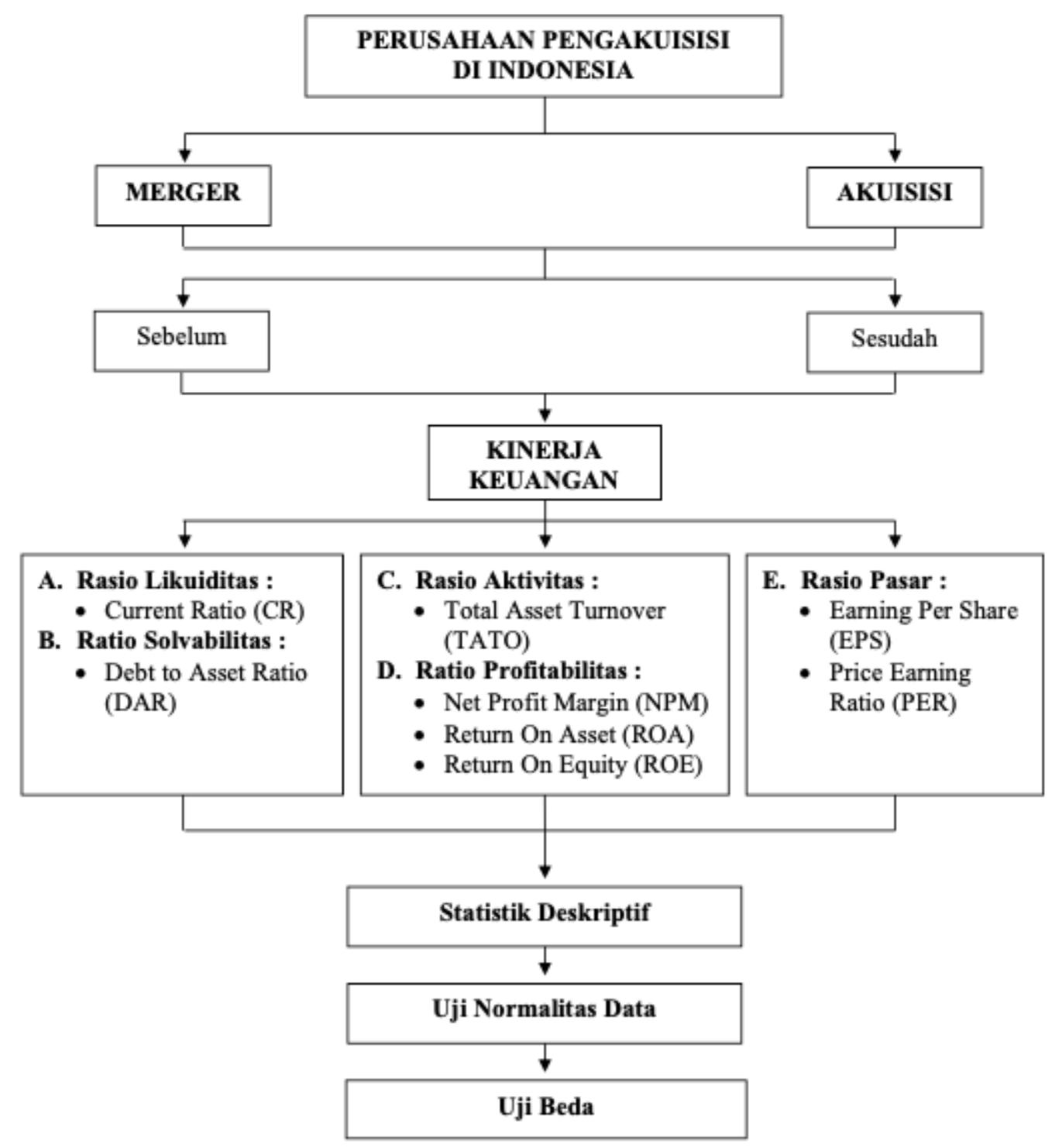

\section{Hipotesis Penelitian}

Ha1 : terdapat perbedaan yang signifikan bagi variabel Current Ratio perusahaan pengakuisisi pada saat sebelum dan setelah proses merger dan akuisisi.

Ha2 : terdapat perbedaan yang signifikan bagi variabel Debt to Asset Ratio perusahaan pada saat sebelum dan setelah proses merger dan akuisisi.

Ha3 : terdapat perbedaan yang signifikan bagi variabel Total Asset Turnover perusahaan pada saat sebelum dan setelah proses merger dan akuisisi.

Ha4 : terdapat perbedaan yang signifikan bagi bagi variabel Net Profit Margin perusahaan pengakuisisi pada saat sebelum dan setelah proses merger dan akuisisi. 
Ha5 : terdapat perbedaan yang signifikan bagi variabel Return On Asset perusahaan pengakuisisi pada saat sebelum dan setelah proses merger dan akuisisi.

Ha6 : terdapat perbedaan yang signifikan bagi variabel Return On Equity perusahaan pengakuisisi pada saat sebelum dan setelah proses merger dan akuisisi.

Ha7 : terdapat perbedaan yang signifikan bagi variabel Earning Per Share perusahaan pengakuisisi pada saat sebelum dan setelah proses merger dan akuisisi.

Ha8 : terdapat perbedaan yang signifikan bagi variabel Price Earnings Ratio perusahaan pengakuisisi pada saat sebelum dan setelah proses merger dan akuisisi.

\section{METODE}

Jenis riset ini adalan jenis riset kuantitatif yang dapat diartikan yakni suatu riset yang dalam prosesnya data yang bersifat kuantitatif ataupun kualitatif yng dikuantitatifkan, adapun jenis data yang dipakai peneliti adalah data sekunder yang diperoleh dari BEI. Dalam riset ini menggunakan desain riset komparatif. Desain riset komparatif merupakan sebuah desain penelitian yang bertujuan untuk memperoleh informasi secara mendasar ingin mencari jawaban secara mendasar terkait dengan asal usul dengan menganalisa hal-hal yang menyebabkan terjadinya suatu kejadian. Adapun tujuan dari kegiatan pelaksanaan penelitian ini untuk meneliti penyebab perbedaan antara variabel yang satu dengan yang lainnya, yang dilakukan dengan meneliti keterkaitan antar variabel. Peneliti menggunakan desain penelitian studi komparatif dengan tujuan peneliti melihat ada tidaknya ketidaksamaan kinerja keuangan antara keadaan sebelum dan setelah proses merger dan akuisisi dilakukan dengan objek penelitian pada entitas yang sudah listed (terdaftar) di bursa efek Indonesia (BEI) dimulai tahun 2013 hingga tahun 2019. Selanjutnya, penelitian ini menggunakan total jumlah objek entitas perusahaan yang dijadikan populasi dari entitas perusahaan yang telah melaksanakan proses merger dan akuisisi yang dibatasi pada perusahaan industri dasar dan kimia yang sudah terdaftar di bursa efek Indonesia (BEI) periode 2013 dengan total 34 perusahaan, metode purposive sampling digunakan dalam penentuan objek riset yang menghasilkan 10 entitas dengan periode pengamatan tujuh tahun dari tahun 2013-2019 maka total sampel sebanyak 70 data observasi. Variabel riset ini adalah kinerja keuangan. Secara khusus yang diteliti dalam variabelpencapaian secara keuangan perusahaan dalam riset ini berfokus pada pencapaian finansial perusahaan (entitas) yang sudah melaksanakan proses merger dan akuisisi. Pencapaian finansial entitas dapat dilihat dengan menggunakan beberapa indikator pengukuran keuangan diantaranya current ratio (CR), debt to asset ratio ( DAR ), total asset turnover (TATO), net profit margin (NPM), return on asset (ROA), return on equity (ROE), earning per share (EPS), price earnings ratio (PER).

Berikut penjelasan masing-masing variable yang akan diteliti secara operasional adalah sebagai berikut:

Tabel 1. Operasional Variabel

\begin{tabular}{|l|l|l|c|}
\hline \multicolumn{1}{|c|}{ Variabel } & \multicolumn{1}{|c|}{ Definisi } & \multicolumn{1}{|c|}{ Pengukuran } & Skala \\
\hline $\begin{array}{l}\text { Current Ratio } \\
\text { (CR) atau rasio } \\
\text { lancar }\end{array}$ & $\begin{array}{l}\text { Suatu rasio pengukuran } \\
\text { keuangan guna melihat } \\
\text { potensi perusahaan } \\
\text { dalam } \\
\text { kewajibannya terhadap } \\
\text { hutang lancar . }\end{array}$ & Aset Lancar & Rasio \\
& (Mutang Lancar & \\
\hline
\end{tabular}




\begin{tabular}{|c|c|c|c|}
\hline $\begin{array}{l}\text { Pengukuran } \\
\text { Utang atau } \\
\text { Debt to Asset } \\
\text { Ratio (DAR) }\end{array}$ & $\begin{array}{l}\text { Suatu pengukuran rasio } \\
\text { yang dapat } \\
\text { menggambarkan } \\
\text { komparasi antara hutang } \\
\text { perusahaan dengan asset } \\
\text { yang dikuasai perusahan }\end{array}$ & $\begin{array}{l}\text { DAR }=\frac{\text { Total Hutang }}{\text { Total Aset }} \\
\text { (sudana I, 2015) }\end{array}$ & Rasio \\
\hline $\begin{array}{l}\text { Total Asset } \\
\text { Turnover } \\
\text { (TATO) atau } \\
\text { Perputaran } \\
\text { Aktiva }\end{array}$ & $\begin{array}{lr}\text { Suatu pengukuran rasio } \\
\text { yang } & \text { dapat } \\
\text { menggambarkan } & \\
\text { keefektifan } & \text { entitas } \\
\text { mendapatkan penjualan } \\
\text { bersih } & \text { dengan } \\
\text { menggunakan } & \text { aktiva } \\
\text { yang ada. } & \\
\end{array}$ & $\begin{array}{l}\text { TATO }=\frac{\text { Penjualan Bersih }}{\text { Total Aktiva }} \\
\text { (Tarigan dan Hatane, 2018) }\end{array}$ & Rasio \\
\hline $\begin{array}{l}\text { Net Profit } \\
\text { Margin } \\
(\mathrm{NPM}) \text { atau } \\
\text { selisih } \\
\text { keuntungan } \\
\text { bersih }\end{array}$ & $\begin{array}{l}\text { Suatu pengukuran rasio } \\
\text { yang memperlihatkan } \\
\text { laba bersih (margin } \\
\text { bersih) yang } \\
\text { dibandingkan dengan } \\
\text { total pendapatan } \\
\text { (penjualan bersih) yang } \\
\text { didapat perusahaan }\end{array}$ & $\begin{array}{l}\text { NPM }=\frac{\text { Laba Bersih }}{\text { Penjualan Bersih }} \\
\text { (Tarigan dan Hatane, 2018) }\end{array}$ & Rasio \\
\hline $\begin{array}{lr}\text { Return } & \text { On } \\
\text { Asset } \quad(\mathrm{ROA}) & \\
\text { atau } & \\
\text { pengembalian } \\
\text { atas investasi }\end{array}$ & $\begin{array}{lr}\text { Suatu } & \text { pengukuran } \\
\text { finansial yang dipakai } \\
\text { untuk menggambarkan } \\
\text { potensi perusahaan } \\
\text { dalam menggunakan } \\
\text { seluruh harta (aktiva) } \\
\text { yang dikuasai entitas } \\
\text { guna memperoleh Profit } \\
\text { after tax (keuntungan } \\
\text { setelah pajak) }\end{array}$ & $\begin{array}{l}\text { ROA }=\frac{\text { Laba Bersih }}{\text { Total Aset }} \\
\text { (Tarigan dan Hatane, 2018) }\end{array}$ & Rasio \\
\hline $\begin{array}{l}\text { Return On } \\
\text { Equity (ROE) }\end{array}$ & $\begin{array}{lr}\text { Suatu pengukuran } \\
\text { keuangan yang dipakai } \\
\text { perusahaan dalam } \\
\text { melihat potensi } \\
\text { perusahaan memperoleh } \\
\text { labaran dengan } \\
\text { memanfaatkan modal } \\
\text { sendiri perusahaan } \\
\end{array}$ & $\begin{array}{c}\text { ROE }=\frac{\text { Laba Bersih }}{\text { Equitas Pemegang }} \\
\text { Saham }\end{array}$ & Rasio \\
\hline $\begin{array}{l}\text { Earning Per } \\
\text { Share (EPS) }\end{array}$ & $\begin{array}{l}\text { Suatu pengukuran yang } \\
\text { dipakai untuk melihat } \\
\text { potensi pendapatan dari } \\
\text { jumlah saham yang ada. }\end{array}$ & $\begin{array}{l}\text { EPS }=\frac{\text { Laba Bersih }- \text { Deviden }}{\text { Jumlah Saham Beredar }} \\
(\text { Tarigan dan Hatane, 2018) }\end{array}$ & Rasio \\
\hline $\begin{array}{l}\text { Price Earnings } \\
\text { Ratio (PER) }\end{array}$ & $\begin{array}{l}\text { Rasio untuk mengukur } \\
\text { membandingkan harga } \\
\text { pasar perlembar } \\
\text { atau market } \\
\text { pershare/MPS } \\
\text { dibandingkan dengan }\end{array}$ & $\begin{array}{l}\text { PER }=\frac{\text { Harga per Saham }}{\text { EPS }} \\
\text { (Tarigan dan Hatane, 2018) }\end{array}$ & Rasio \\
\hline
\end{tabular}




\begin{tabular}{|l|l|l|l|}
\hline laba per lembar saham & & \\
atau sering disebut & & \\
earning pershare/EPS. & & \\
Price Earnings Ratio & & \\
(PER) dapat & & \\
memperlihatkan tingkat & & \\
pertumbuhan & & \\
perusahaan. & & \\
\hline
\end{tabular}

\section{Uji Normalitas}

Uji normalitas biasa digunakan peneliti guna melakukan pengujian dari model regresi, distribusi normal dimiliki oleh variable residual atau variable pengganggu (Ghozali I, 2018). Alat uji statistik dapat ditentukan oleh uji normalitas yang semestinya dipakai guna keperluan uji hipotesis. Jika data terdistribusi yang dihasilkan normal maka dapat menggunakan tes parametrik (Paired sample t-test). Akan tetapi jika data yang dihasilkan terdistribusi tidak normal maka dapat memilih alat uji berupa uji statistik non parametrik (wilcoxon sign test). Menurut riset sebelumnya (Khasanah, 2015) sebenarnya terdapat banyak cara yang digunakan untuk menguji normalitas data, salah satu diantaranya uji normalitas One Sample Kolmogorov Smirnov Test yang digunakan pada riset ini. Uji normalitas data dapat menggunakan kriteriakriteria agar data dapat diterima atau ditolak yang diperoleh dari total keseluruhan populasi yang diperoleh terdistrisbusi normal yang didasarkan pada P-Value sebagai berikut:

Nilai P-Value merupakan hasil dari data populasi terdistribusi secra normal yang selanjutnya dijadikan sebagai penentu kriteria diterima ataukah data ditolak untuk digunakan sebagai data yang akan dilakukan uji normalitas. Dengan acuan :

a. Apabila nilai $P$-Value $<\alpha$, maka hasilnya data tidak normal

b. Apabila nilai $P$-Value $>\alpha$, maka hasilnya data normal

Keterangan: $P$-Value adalah istilah significance (Sig), dengan nilai alfa $(\alpha)$ yang digunakan dalam kegiatan riset ini adalah sebesar $5 \%$.

\section{Teknik Analisis}

Analisis data merupakan langkah yang sangat penting dalam sebuah penelitian. Analisis data adalah kegiatan setelah data dari seluruh responden atau sumber data lain terkumpul sesuai dengan Sugiyono (2017). Setelah data sudah terkumpul dan sudah lengkap, maka data harus dianalisis menggunakan analisis kuantitatif seperti model matematika, model statistik dan model ekonomitrik.Hasil analisis tersebut disajikan dalam bentuk angka-angka yang kemudian dijelaskan dalam suatu uraian kalimat. Berikut adalah analisis kuantitatif yang diteliti :

\section{Analisis Statistik Deskriptif}

Statistik deskriptif memberikan gambaran atau deskriptif suatu data yang dilihat dari nilai ratarata (mean), standar deviasi, dan varian dengan prosedur sebagai berikut (Khasanah, 2015) :

1. Menentukan tingkat rata-rata (mean), standar deviasi dan varian indicator kinerja keuangan perusahaan dari rasio keuangan (Current Ratio, Debt to Asset Ratio, Total Asset Turnover, Net Profit Margin, Return On Asset, Return On Equity, Earning Per Share, Price Earnings Ratio) 2 tahun sebelum dan 4 tahun sesudah merger dan akuisisi ditinjau dari kinerja perusahaan yang terdaftar di BEI.

2. Menentukan perbedaan mean (naik/turun) indicator keuangan perusahaan antara sebelum dan sesudah merger dan akuisisi. 


\section{Uji Hipotesis}

Uji statistic parametrik dan uji statistic non parametrik dipakai sebagai alat uji hipotesa yang diajukan. Uji beda atau uji komparatif dijadikan sebagai penentu dua sampel yang ada tidak berkaitan memiliki rata-rata. SPSS digunakan sebagai alat bantu perhitungan uji beda menggunakan kriteria apabila hasil riset yaitu signifikansi $\leq$ taraf signifikansi 0,05 (5\%) maka ada perbedaan, sedangkan jika hasil riset yaitu signifikansi taraf signifikansi 0,05 (5\%) maka tidak ada perbedaan.

Ada beberapa tahapan analisis yang dilakukan dalam pelaksanaan penelitian ini diantaranya:

a. Melakukan perhitungan masing-masing rasio keuangan yang menjadi indikator penelitian

b. Melakukan proses Analisa dari laporan keuangan yang ada baik dimulai dari kondisi sebelum proses penggabungan dan setelah dilakukannya merger dan akuisisi selama periode pengamatan riset

c. Melakukan tahapan analisis dari berdasarkan ada tidaknya kesamaan yang timbul pada pencapaian finansial entitas selama masa pengamatan dimulai dari kondisi sebelum pelaksanaan proses penggabungan usaha hingga setelah dilakukannya merger serta akuisisi yang diuji dengan memakai uji Wilcoxon Signed Rank Test dengan nilai 5\% taraf signifikansinya $(\alpha)$

Kriteria uji hipotesa:

1. Apabila nilai Sig $\mathrm{t}>0,05$, maka hasilnya adalah Ho diterima.

Apabila nilai Sig t $<0,05$, maka hasilnya adalah Ho ditolak

Tabel 2. Uji Normalitas

\begin{tabular}{|c|c|c|c|c|c|c|c|c|c|}
\hline $\begin{array}{c}\text { Varia } \\
\text { bel }\end{array}$ & $\begin{array}{c}2 \text { Tahun } \\
\text { Sebelum } \\
\text { M\&A }\end{array}$ & $\begin{array}{c}1 \text { Tahun } \\
\text { Sebelum } \\
\text { M\&A }\end{array}$ & $\begin{array}{c}\text { TAHUN } \\
\text { M\&A }\end{array}$ & $\begin{array}{c}1 \text { Tahun } \\
\text { Sesudah } \\
\text { M\&A }\end{array}$ & $\begin{array}{c}2 \text { Tahun } \\
\text { Sesudah } \\
\text { M\&A }\end{array}$ & $\begin{array}{c}3 \text { Tahun } \\
\text { Sesudah } \\
\text { M\&A }\end{array}$ & $\begin{array}{c}4 \text { Tahun } \\
\text { Sesudah } \\
\text { M\&A }\end{array}$ & $\begin{array}{c}\text { Taraf } \\
\text { Sig }\end{array}$ & $\begin{array}{c}\text { Keterang } \\
\text { an }\end{array}$ \\
\hline CR & 0,200 & 0,200 & 0,188 & 0,810 & 0,200 & 0,200 & 0,200 & 0,05 & Normal \\
\hline DAR & 0,200 & 0,200 & 0,200 & 0,700 & 0,200 & 0,200 & 0,200 & 0,05 & Normal \\
\hline TATO & 0,200 & 0,200 & 0,052 & 0,200 & 0,095 & 0,200 & 0,200 & 0,05 & Normal \\
\hline NPM & 0,200 & 0,200 & 0,200 & 0,200 & 0,200 & 0,200 & 0,200 & 0,05 & Normal \\
\hline ROA & 0,200 & 0,200 & 0,200 & 0,200 & 0,200 & 0,200 & 0,200 & 0,05 & Normal \\
\hline ROE & 0,126 & 0,200 & 0,200 & 0,200 & 0,200 & 0,200 & 0,650 & 0,05 & Normal \\
\hline EPS & 0,200 & 0,155 & 0,200 & 0,200 & 0,200 & 0,200 & 0,200 & 0,05 & Normal \\
\hline PER & 0,148 & 0,095 & 0,085 & 0,200 & 0,200 & 0,200 & 0,660 & 0,05 & Normal \\
\hline
\end{tabular}

Sumber: Output hasil olah data SPSS versi 25, 2021

Berdasarkan tabel 2 (hasil dan pembahasan) dijelaskan bahwa pengujian normalitas melalui uji kolmogrov-smirnov memperlihatkan nilai sig variabel current ratio (CR), debt to asset ratio (DAR), total asset turnover (TATO), net profit margin (NPM), return on asset (ROA), return on equity (ROE), earning per share (EPS) serta price earning ratio (PER) lebih besar dari nilai a $(>0,05)$, dari uraian diatas maka dapat dijelaskan pencapaian finansial selama masa riset menghasilkan data yang sebarannya normal hal ini mendukung asumsi data normal terpenuhi, selain itu analisis statistic parametrik dengan uji beda dipakai pada saat uji hipotesis. 


\section{Uji Hipotesis}

Perbedaan Pencapaian Finansial Antara Keadaan Sebelum hingga Setelah Proses Merger
Dan Akuisisi dilakukan Berdasarkan Rasio Keuangan Dengan Indikator (Current Ratio)

Berdasarkan data hasil perhitungan SPSS V.25 pada duatahun sebelum dan dua tahun setelah proses merger serta akuisisi dihasilkan nilai $t$ hitung $>t$ tabel $(2,443>2,201)$ dan tingkat signifikan $<0,05(0,037)$, kondisi setahun sebelum penggabungan dan tiga tahun sesudah proses Merger serta Akuisisi diperoleh nilai t hitung $>\mathrm{t}$ tabel $(2,570>2,201$ dan tingkat signifikan $<0,05(0,030<0,05)$ maka diperoleh kesimpulan Ho tidak diterima sementara Ha diterima, artinya hasil uji yang telah dilakukan menunjukan bahwa ditemukan perbedaan kinerja keuangan yang ada antara kondisi sebelum penggabungan hingga sesudah dilakukannya proses merger serta akuisisi berdasarkan pengukuran finansial dengan menggunakan current ratio (CR).

Terdapat ketidaksamaan hasil current ratio (CR) antara kondisi sebelum penggabungan dan setelah dilakukannya proses merger serta akuisisi yang disebabkan setelah melakukan merger dan akuisisi suatu entitas mempunyai potensi guna memenuhi seluruh kewajiban jangka pendek yang berakibat timbulnya kepercayaan pihak luar dalam mendukung kelancaran operasional usaha perusahaan tersebut, (Cahyarini, 2017). Hal ini di dukung oleh teori keagenan dimana manajemen perusahaan berupaya terus untuk meningkatkan kepercayaan terhadap masyarakat luas supaya citra dan nama baik perusahaan tinggi yang berakibat pada peningkatan kesejahteraan pemilik saham dan kontinyuitas entitas.

Hal ini sesuai dengan riset oleh Laiman \& Hatane (2017), yang menjelaskan ada ketidaksamaan hasil pada periode setahun sebelum penggabungan usaha dengan setahun dan tiga tahun sesudah dilaksanakannya proses merger serta akuisisi, yang dapat diartikan bahwa tingkat efisiensi entitas dalam opersionalnya dengan penggunaan aktiva lancarnya supaya dapat mengatur kewajiban lancar yang ada semakin meningkat pasca merger serta akusisi. Perusahaan yang melakukan proses merger dan akuisisi mengakibatkan peningkatan tingkat likuiditasnya. Namun hasil riset ini juga tidak sesuai dengan riset oleh Gustina (2017) yang memperlihatkan hasil tidak ada perbedaan hasil yang berarti dari tingkat current ratio antara kondisi sebelum dan setelah dilakukannya proses merger serta akuisisi.

\section{Perbedaan Pencapaian Keuangan Antara Kondisi Sebelum dengan Setelah Proses Merger serta Akuisisi Berdasarkan Rasio Finansial melalui Indikator Debt Asset Ratio}

Berdasarkan hasil perhitungan SPSS V.25 pada dua tahun kondisi sebelum dengan tiga tahun setelah proses merger serta akuisisi diperoleh nilai thitung $>t$ tabel $(2,732>2,201)$ dan tingkat signifikan $<0,05(0,023<0,05)$, dua tahun kondisi sebelum dengan empat tahun setelah proses merger serta akuisisi diperoleh nilai $t$ hitung $>t$ tabel $(2,830>2,021)$ dan tingkat signifikan $<0,05(0,020<0,05)$, setahun kondisi sebelum dengan tahun pelaksanaan proses merger serta akuisisi diperoleh nilai $t$ hitung $>t$ tabel $(4,045>2,201)$ dan tingkat signifikan $<$ $0,05(0,003<0,05)$, pada setahun kondisi sebelum serta dua tahun setelah proses merger serta akuisisi diperoleh nilai t hitung $>\mathrm{t}$ tabel $(3,258>2,201)$ dan tingkat signifikan $<0,05(0,010<$ 0,05), pada setahun kondisi sebelum dengan kondisi tiga tahun setelah proses merger serta akuisisi diperoleh nilai $t$ hitung $>\mathrm{t}$ tabel $(2,775>2,201)$ dan tingkat signifikan $<0,05(0,022<$ $0,05)$, dan pada setahun kondisi sebelum dengan empat tahun setelah proses merger dengan akuisisi diperoleh nilai $\mathrm{t}$ hitung $>\mathrm{t}$ tabel $(2,726>2,201)$ dan tingkat signifikan $<0,05(0,023<$ 0,05) maka dapat diperoleh kesimpulan Ho tidak diterima sementara Ha diterima, artinya hasil uji yang telah dilakukan menunjukan ada ketidaksamaan hasil perbandingan pencapaian finansial entitas antara kondisi sebelum dengan setelah proses merger serta akuisisi didasarkan hasil rasio keuangan debt to asset rasio (DAR) namun dengan arah negatif. Hal ini menunjukan 
rata-rata sebelum proses merger serta akuisisi pada Debt to Asset Rasio (DAR) hasil yang didapatkan tidak lebih tinggi apabila dikomparasi dengan proses setelah merger serta akuisisi.

Hasil penilaian memperlihatkan ada ketidaksamaan Debt To Asset Rasio (DAR) antara kondisi sebelum dengan kondisi setelah dilaksanakannya proses merger serta akuisisi dikarenakan DAR mencerminkan tingkat efisiensi yang baik, perusahaan berhasil melakukan efisiensi penggunaan biaya operasional dibandingkan dengan perolehan pendapatan operasi perusahaan. Hal ini dapat diartikan bahwa manajemen baru hasil proses merger serta akuisisi dapat melakukan kontrol secara operasional sehingga dapat menghasilkan optimalisasi keuntungan perusahaan (Serenade, 2019). Hal ini di dukung oleh teori keagenan dimana pihak manajemen memberikan informasi kepada pricipal (pemegang saham) mengenai pencapaian finansial entitas perusahaan sesudah pelaksanaan proses merger dan akuisisi yang dapat mempengaruhi peningkatan asset perusahaan yang dipakai sebagai jaminan atas hutang yang dimiliki oleh perusahaan. Hal ini sama dengan riset oleh (Kusumaningtyas \& Handayani, 2018) yang menjelaskan Debt to Asset Ratio (DAR) mengalami perbedaan secara berarti. Hal tersebut terjadi dikarenakan DAR mengalami tingkat peningkatan setelah perusahaan melakukan proses merger serta akuisisi apabila dikomparasi antara kondisi sebelum merger serta akuisisi. Hal tersebut terjadi karena entitas mengeluarkan banyak pengeluaran melalui hutang guna mendapatkan asset entitas dibandingkan menggunakan modal walaupun tingkat risiko perusahaan dalam melunasi kewajibannya semakin tinggi. Akan tetap hasil riset ini tidak sesuai dengan riset yang dilaksanakan oleh (Esterlina \& Firdausi, 2017) yang menjelaskan DAR memperlihatkan tidak adanya ketidaksamaan yang berarti dengan membandingkan kondisi sebelum dengan sesudah proses merger serta akuisisi dilakukan perusahaan.

\section{Perbedaan Pencapaian Finansial Antara Kondisi Sebelum dengan Setelah Merger Serta Akuisisi didasarkan Ukuran Penilaian Keuangan Dengan Indikator Total Asset Turnover}

Berdasarkan hasil perhitungan SPSS V.25 pada periode dua tahun kondisi sebelum dengan tahun pelaksanaan proses merger serta akuisisi diperoleh nilai $t$ hitung $>t$ tabel $(2,424>$ $2,021)$ dan tingkat signifikan $<0,05(0,038<0,05)$, pada periode dua tahun kondisi sebelum dengan setahun setelah pelaksanaan proses merger serta akuisisi diperoleh nilai $t$ hitung $>t$ tabel $(2,622>2,021)$ dan tingkat signifikan $<0,05(0,028<0,05)$, Periode dua tahun kondisi sebelum dengan dua tahun setelah pelaksanan proses merger serta akuisisi diperoleh nilai thitung $>\mathrm{t}$ tabel $(2,839>2,201)$ dan tingkat signifikan $<0,05(0,019<0,05)$, periode dua tahun kondisi sebelum dengan empat tahun setelah pelaksanaan proses merger serta akuisisi diperoleh nilai thitung $>\mathrm{t}$ tabel $(3,175>2,201)$ dan tingkat signifikan $<0,05(0,011<0,05)$, periode kondisi setahun sebelum dengan tahun pelaksanaan proses merger serta akuisisi diperoleh nilai $t$ hitung $>\mathrm{t}$ tabel $(2,507>2,201)$ dan tingkat signifikan $<0,05(0,003<0,05)$, pada periode kondisi setahun sebelum dengan setahun setelah pelaksanaan proses merger serta akuisisi diperoleh nilai $\mathrm{t}$ hitung $>$ t tabel $(2,759>2,201)$ dan tingkat signifikan $<0,05(0,022<0,05)$, pada periode setahun sebelum dengan dua tahun setelah pelaksanaan proses merger serta akuisisi diperoleh nilai $\mathrm{t}$ hitung $>$ t tabel $(3,494>2,201)$ dan tingkat signifikan $<0,05(0,007<0,05)$, dan pada periode setahun sebelum dan empat tahun setelah proses merger serta akuisisi diperoleh nilai $t$ hitung $>t$ tabel $(3,833>2,201)$ dan tingkat signifikan $<0,05(0,004<0,05)$ maka bisa diambil kesimpulan Ho ditolak dan Ha diterima, artinya adanya perbedaan dari komparasi antara pencapaian finansial kondisi sebelum pelaksanaan dengan setelah pelaksanaan proses merger serta akuisisi yang didasarkan dari pengukuran keuangan TATO.

Ada ketidaksamaan Total Asset Turnover (TATO) kondisi sebelum dengan sesudah pelaksanaan proses merger serta akuisisi dikarenakan setelah proses merger serta akuisisi entitas (perusahaan) memiliki kemampuan dalam pengelolaan harta (aktiva) yang ada pada perusahaan sehingga operasional perusahaan menjadi lebih efektif didalam penggunaan aset yang diharapkan memperoleh sales yang maksimal, penjualan yang maksimal (tinggi) 
berdampak pada semakin pesatnya pertumbuhan perusahaan (sudana, 2015). Hal ini didukung oleh teori keagenan dimana manajer mempunyai peran penting untuk mengambil keputusan merger serta akuisisi yang dilakukan entitas, dimana manajer akan mengambil suatu kebijakan entitas untuk meningkatkan penjualan yang akan mempengaruhi pada pertumbuhan perusahaan sehingga pemanfaatan aset dapat optimal.

Hal ini sesuai dengan hasil riset oleh (Esterlina \& Firdausi, 2017) dengan menjelaskan bahwa muncul ketidaksamaan nilai TATO yang berarti pada periode kondisi setahun sebelum proses merger serta akuisisi dengan dua tahun dan tiga tahun setelah proses merger serta akuisisi dilakukan, kondisi ini pun dialami pada periode dua tahun sebelum proses merger serta akuisi dengan tiga tahun setelah proses merger serta akuisisi dilakukan, serta tiga tahun sebelum proses merger dan akuisisi dengan tiga tahun sesudah pelaksanaan proses merger serta akuisisi terjadi. Sehingga disimpulkan terjadinya perbedaan tersebut dikarenakan setelah terjadi pelaksanaan proses merger dan akuisi (penggabungan usaha perusahaan) dengan terjadinya proses pengambilalih memiliki penambahan aktiva.

Namun, hasil riset ini tidak sesuai dengan hasil riset yang dilakukan oleh Fitriasari (2016) yang menunjukan tidak ada perbedaan nilai Total Asset Turnover (TATO) pada saat sebelum proses merger serta akuisisi dibandingkan dengan setelah pelaksanaan proses marger serta akusisi.

\section{Perbedaan Pencapaian Finansial Entitas Antara Kondisi Sebelum Dengan Setelah Merger Serta Akuisisi didasarkan pada Rasio Keuangan melalui Indikator Net Profit Margin atau NPM}

Berdasarkan hasil perhitungan SPSS V.25 pada periode dua tahun sebelum dan tahun pelaksanaan proses merger serta akuisisi diperoleh nilai $t$ hitung $<\mathrm{t}$ tabel $(0,457<2,201)$ dan tingkat signifikan $>0,05(0,658>0,05)$, periode dua tahun sebelum dan periode setahun sestelah proses merger serta akuisisi diperoleh nilai t hitung $<\mathrm{t}$ tabel $(0,644<2,201)$ dan tingkat signifikan $>0,05(0,536>0,05)$, periode dua tahun sebelum dan dua tahun setelah pelaksanaan proses merger serta akuisisi diperoleh nilai $t$ hitung $<$ t tabel $(-0,181<-2,201)$ dan tingkat signifikan $>0,05(0,861>0,05)$, periode dua tahun sebelum dan tiga tahun setelah pelaksanaan proses merger serta akuisisi diperoleh nilai $t$ hitung $<\mathrm{t}$ tabel $(-0,165<-2,201)$ dan tingkat signifikan>0,05 $(0,873>0,05)$, periode dua tahun sebelum dan empat tahun setelah pelaksanaan proses merger serta akuisisi diperoleh nilai $t$ hitung $<\mathrm{t}$ tabel $(-0,624<-2,201)$ dan tingkat signifikan $>0,05(0,548>0,05)$, periode setahun sebelum dan tahun pelaksanaan proses merger serta akuisisi diperoleh nilai $t$ hitung $<\mathrm{t}$ tabel $(0,768<2,201)$ dan tingkat signifikan $>0,05$ $(0,462>0,05)$, pada periode setahun sebelum dan setahun setelah pelaksanaan proses merger serta akuisisi diperoleh nilai t hitung $<\mathrm{t}$ tabel $(1,526<2,201)$ dan tingkat signifikan $>0,05(0,161$ $>0,05)$, pada periode setahun sebelum dan dua tahun setelah proses merger serta akuisisi diperoleh nilai t hitung $<\mathrm{t}$ tabel $(0,300<2,201)$ dan tingkat signifikan $>0,05(0,771>0,05)$, pada setahun sebelum dan tiga tahun setelah pelaksanaan proses merger serta akuisisi diperoleh nilai t hitung $<\mathrm{t}$ tabel $(0,430<2,201)$ dan tingkat signifikan $>0,05(0,677>0,05)$, pada periode setahun sebelum dan empat tahun setelah pelaksanaan proses merger dan akuisisi diperoleh nilai $t$ hitung $<\mathrm{t}$ tabel $(0,039<2,201)$ dan tingkat signifikan $>0,05(0,970>0,05)$ maka dapat ditarik kesimpulan Ho dapat diterima diterima sementara Ha ditolak, artinya tidak ada ketidaksamaan pencapaian finansial pada saat sebelum dengan setelah pelaksanaan proses merger serta akuisisi yang didasarkan pada penilaian indikator rasio keuangan yakni Net Profit Margin (NPM).

Net Profit Margin (NPM) adalah laba bersih setelah dipotong tax penjualan yang memiliki fungsi mengetahui besarnya laba (margin) bersih dengan total pendapatan bersih yang didapatkan oleh entitas atau perusahaan. Tujuan perusahaan mengambil langkah penggabungan usaha (merger dan akuisisi) adalah untuk memaksimalkan pendapatan bersih yang diperoleh 
perusahaan, (Serenade, 2018). Tujuan tersebut tidak tercapai dikarenakan perusahaan tidak melakukan secara optimal untuk meningkatkan penjualan sehingga laba yang dihasilkan tidak meningkat. Kondisi ini sesuai dengan teori keagenan yang menyatakan bahwa pengambilan suatu kebijakan yang ada dalam entitas atau perusahaan pesti terdapat motif lain yang juga dilakukan manager dalam proses pengambilan kebijakn, sehingga berakibat secara langsung atau tidak langsung pada penilaian prestasi serta mutu kebijakan yang akan diputuskan hal tersebut juga berdampak pada adanya perubahan dalam sasaran dan tujuan pelaksanaan proses penggabungan usaha (merger dan akuisisi). Adapun permasalahan kepentingan yang mucul didalam internal entitas atau perusahaan yakni tidak optimalnya pelaksanaan penggabungan usaha (merger dan akuisisi) itu sendiri. Pernyataan diatas juga sesuai dengan hasil riset yang dilaksanakan oleh Gustina (2017) yang menjelaskan bahwa tidak ada perbedaan yang berarti pada indikator net profit margin (NPM) pada saat sebelum dengan setelah terjadinya proses merger serta akuisisi antar entitas, hal ini terjadi disebabkan oleh entitas (perusahaan) tidak mampu menaikkan tingkat penjualan sehingga berdampak pada laba pun tidak optimal sehingga tidak terasa dampak kenaikan nilai NPM setelah proses merger dan akuisisi. Akan tetapi dalam penelitian Sajow dan Keles (2017) menjelaskan justru ada ketidaksamaan yang berarti pada saat sebelum dan setelah proses pelaksanaan merger serta akuisisi yang dilakukan oleh entitas atau perusahaan.

\section{Perbedaan Pencapaian Finansial Antara Kondisi Sebelum dengan Setelah Merger serta Akuisisi Didasarkan Ukuran finansial dengan Indikator Return On Asset}

Berdasarkan hasil perhitungan SPSS V.25 pada periode dua tahun sebelum dengan setahun setelah proses merger serta akuisisi maka diperoleh nilai t hitung $>$ t tabel $(2,482>$ $2,201)$ dan tingkat signifikan $<0,05(0,035<0,05)$, periode dua tahun sebelum dengan dua tahun setelah proses merger serta akuisisi diperoleh nilai $t$ hitung $>t$ tabel $(2,254>2,021)$ dan tingkat signifikan $<0,05(0,051<0,05)$, periode setahun sebelum dengan setahun sesudah proses merger serta akuisisi diperoleh $t$ hitung $>t$ tabel $(2,198>2,201)$ dan tingkat signifikan $<0,05(0,018<$ $0,05)$, dan pada periode setahun sebelum dengan dua tahun setelah proses merger serta akuisisi diperoleh $t$ hitung $>t$ tabel $(2,789>2,201)$ dan tingkat signifikan $<0,05(0,021<0,05)$ maka dapat ditarik sebuah kesimpula Ho ditolak sementara Ha dapat diterima, artinya terdapat perbedaan yang diperoleh dari capaian finansial pada saat sebelum dengan setelah pelaksanaan proses merger serta akuisisi dengan menggunakan indikator return on asset (ROA).

Ditemukan ketidaksamaan antara Return On Asset (ROA) yang terjadi pada saat sebelum dengan setelah pelaksanaan proses merger serta akuisisi yang disebabkan entitas setelah pelaksanan proses penggabungan usaha (merger dan akuisisi) entitas atau perusahaan mempunyai kewenangan guna menggunakan semua aktiva yang ada guna memperoleh laba dengan didukung oleh kesuksesan manajemen pasca proses penggabungan usaha dalam mengatur margin yang ada (sudana, 2015). Hal ini di dukung oleh teori keagenan karena manajemen akan memberikan informasi positif kepada principal mengenai kondisi kinerja keuangan perusahaan untuk meningkatkan laba perusahaan tersebut. Meningkatnya laba dapat memengaruhi pengungkapan informasi secara menyeluruh yang berakibat pada rendahnya biaya keagenan. Manajemen akan lebih mempunyai motivasi dalam mengungkapkan informasi karena didorong pada besarnya laba entitas sehongga biaya yang diperlukan untuk pengungkapan dapat tercukupi.

Pernyataan diatas sesuai dengan riset yang sudah dilaksanakan oleh (Esterlina \& Firdausi, 2017) dengan memakai Uji wilcoxon menyatakan terjadinya ketidaksamaan secara signifikan ROA saat periode setahun sebelum yang dikomparasi dengan tiga tahun setelah proses penggabungan usaha (merger serta akuisisi) dengan mean ROA sesudah proses merger dan akuisisi lebih besar dari mean ROA sebelum pelaksaan proses merger dan akuisisi. Hal ini memperlihatkan bahwa kinerja entitas (perusahaan) menjadi mengingkat setelah proses merger 
dan akuisisi dilakukan. Kondisi ini terjadi dikarenakan perusahaan cenderung lebih efisiein dalam memanfaatkan asetnya untuk mendapatkan keuntungan (laba) sehingga terlihat bahwa porsi kenaikan laba bersih jauh lebih besar apabila dikomparasi dengan porsi kenaikan total asset. Akan tetapi pernyataan ini tidak sesuai dengan hasil riset yang dilaksanakan oleh (Laiman \& Hatane, 2017) yang menggambarkan hasil pengujian yang sama antara keadaan sebelum dengan setelah proses merger serta akuisisi dengan menggunakan ROA sebagai indikator rasio keuangannya.

\section{Perbedaan Pencapaian Finansial Entitas Antara Kondisi Sebelum dengan Setelah Merger dengan Akuisisi Didasarkan Ukuran Keuangan Dengan Indikator Return On Equity}

Berdasarkan hasil perhitungan SPSS V.25 Pada periode dua tahun sebelum dengan tahun pelaksanaan proses merger serta akuisisi diperoleh nilai $t$ hitung $>t$ tabel $(2,530>2,201)$ dan tingkat signifikan $<0,05(0,032<0,05)$, periode dua tahun sebelum dengan setahun sesudah proses merger serta akuisisi diperoleh nilai $t$ hitung $>t$ tabel $(2,430>2,201)$ dan tingkat signifikan $<0,05(0,038<0,05)$ maka dapat diambil sebuah kesimpulan yakni Ho ditolak sementara nilai Ha dapat diterima, artinya hasil uji yang telah dilakukan menunjukan bahwa ada perbedaan antara pencapaian finansial periode diantara saat sebelum dengan setelah pelaksanaan proses merger serta akuisisi yang didasarkan rasio keuangan return on equity (ROE).

Ada ketidaksamaan hasil pengukuran return on equity (ROE) pada periode sebelum dan sesudah pelaksanaan proses merger serta akuisisi dikarenakan pasca dilakukannya merger serta akuisisi perusahaan mempunyai potensi memaksimalkan seluruh ekuitas yang ada diperusahaan guna memperoleh laba maksimum yang tentunya harus didukung oleh kesuksesan manajemen baru hasil penggabungan usaha dalam pengelolaan margin (sudana, 2015). Hal ini di dukung oleh teori keagenan karena manajemen akan memberikan informasi positif kepada principal mengenai kondisi kinerja keuangan perusahaan untuk meningkatkan laba perusahaan tersebut. Meningkatnya laba berdampak atas semakin besarnya pengungkapan nformasi finansial entitas yang mengakibatkan rendahnya biaya agen. Entitas dapat mendorong manajemen melakukan pengungkapan informasi finansial entitas yang ada diakibatkan tercukupinya biaya pengungkapan yang yang didasari oleh besarnya keuntungan yang diperoleh perusahaan.

Gustina (2017) menjelaskan hasil penelitianya yakni ROE mengalami perbedaan signifikan untuk periode setahun sebelum dibandingkan dengan setahun pasca dilakukannya merger serta akuisisi. Hasil yang diperoleh ditemukan ketidaksamaan yang signifikan dari pengukuran ROE entitas pasca dilakukannya proses merger serta akuisisi, hal ini disebabkan entitas semaksimal mungkin bisa menggunakan modal yang ada guna keuntungan diperoleh secara maksimal. Hal ini dapat diartikan perusahaan dapat memaksimalkan modal sendiri tanpa bantuan modal asing sehingga tujuan perusahaan tercapai. Akan tetapi hasil riset tidaklah sama dengan hasil riset yang diteliti oleh Laiman \& Hatane (2017) yang memperlihatkan hasil uji hipotesis pada indikator Return On Equity disimpulkan tidak terdapat hasil sama yang cukup signifikam pada Return On Equity sebelum dengan pasca dilaksanakan proses merger serta akuisisi.

\section{Perbedaan Kinerja Keuangan Antara Sebelum dengan Pasca Merger serta Akuisisi Berdasarkan Rasio Keuangan dengan Indikator (Earning Per Share)}

Berdasarkan hasil perhitungan SPSS V.25 pada periode dua tahun sebelum dengan tahun pelaksanaan proses merger serta akuisisi diperoleh nilai $t$ hitung $<\mathrm{t}$ tabel $(-0,552<-2,201)$ dan tingkat signifikan $>0,05(0,594>0,05)$, periode dua tahun sebelum dengan setahun pasca proses merger serta akuisisi diperoleh nilai $t$ hitung $<\mathrm{t}$ tabel $(1,351<2,201)$ dan tingkat signifikan $>0,05$ $(0,210>0,05)$, periode dua tahun sebelum dengan dua tahun pasca proses merger serta akuisisi diperoleh nilai $t$ hitung $<\mathrm{t}$ tabel $(-0,137<-2,201)$ dan tingkat signifikan $>0,05(0,894>0,05)$, 
periode dua tahun sebelum dengan tiga tahun pasca proses merger serta akuisisi diperoleh nilai thitung $<\mathrm{t}$ tabel $(0,189<2,201)$ dan tingkat signifikan $>0,05(0,855>0,05)$, periode dua tahun sebelum dengan empat tahun pasca proses merger serta akuisisi diperoleh nilai $t$ hitung $<t$ tabel $(-0,861<-2,201)$ dan tingkat signifikan $>0,05(0,412>0,05)$, periode setahun sebelum dengan tahun pelaksanaan proses merger serta akuisisi diperoleh nilai t hitung $<\mathrm{t}$ tabel $(0,562<2,201)$ dan tingkat signifikan $>0,05(0,588>0,05)$, periode setahun sebelum dengan setahun pasca proses merger serta akuisisi diperoleh nilai $t$ hitung $<\mathrm{t}$ tabel $(1,475<2,201)$ dan tingkat signifikan>0,05 $(0,179>0,05)$, pada periode setahun sebelum dengan dua tahun pasca pelaksanaan merger dan akuisisi diperoleh nilai t hitung <t tabel $(0,887<2,201)$ dan tingkat signifikan $>0,05(0,398>0,05)$, pada setahun sebelum dengan tiga tahun pasca proses merger serta akuisisi diperoleh nilai $t$ hitung $<\mathrm{t}$ tabel $(0,907<2,201)$ dan tingkat signifikan $>0,05(0,388$ $>0,05)$, pada periode setahun sebelum dengan empat tahun pasca proses merger serta akuisisi diperoleh nilai t hitung $<\mathrm{t}$ tabel $(0,499<2,201)$ dan tingkat signifikan $>0,05(0,630>0,05)$. Dari hasil riset diatas bisa diuraikan bahwa Ho dapat diterima sementara Ha tidak dapat diterima, artinya hasil uji yang telah dilakukan menunjukan tidak ditemukan hasil yang berbeda pada capaian finansial antara sebelum dengan pasca pelaksanaan proses merger serta akuisisi yang berasal dari rasio keuangan Earning Per Share (EPS).

Earning Per Share (EPS) digunakan guna memperlihatkan keuntungan yang diperoleh oleh investor yang dihasilkan dari setiap lembar saham yang ada. Laba dan nilai perusahaan yang tinggi menjadi sasaran dari pelaksanaan merder serta akuisisi yang dilakukan oleh perusahaan (Serenade, 2018). Tidak tercapainya tujuan tersebut bisa dikarenakan perusahaan belum cukup mampu meningkatkan pertumbuhan keuntungan perusahaan. Teori keagenan mendukung pernyataan diatas yang menjelaskan bahwa dalam proses pengambilan sebuah kebijakan perusahaan atau entitas pasti terdapat motif lain yang dilaksanakan manager guna mengambil sebuah kebijakan sehingga mempengaruhi secara langsung atau tidak langsung dalam kebijakan merger dan akuisisi sehingga dalam kebijakannya mengalami perubahan dalam tujuan pelaksanaannya.

Hal ini sesuai dengan riset oleh Sumarah (2018), yang menghasilkan tidak terdapat hal yang beda secara berarti antara sebelum dengan pasca pelaksanaan proses merger serta akuisisi hal tersebut terjadi disebabkan entitas (perusahaan) belum bisa meningkatkan pertumbuhan keuntungan perusahaan. Perusahaan juga mengalami penurunan nilai EPS kondisi ini terjadi diakibatkan keuntungan perusahaan naik serta diikuti peningkatan jumlah saham yang beredar mengakibatkan nilai EPS turun.

Namun, penelitian ini tidak sama dengan hasil riset oleh (Esterlina \& Firdausi, 2017) menyatakan dalam risetnya tidak ditemukan adanya perbedaan secara berarti pada ukuran EPS, serta terjadi peningkatan nilai rata-rata EPS antara semula jika dibandingkan pasca proses merger serta akuisisi.

\section{Perbedaan Capaian Finansial Antara Kondisi Sebelum dengan Pasca Merger serta Akuisisi Didasarkan ukuran Finansial dengan Indikator Price Earnings Ratio(PER)}

Berdasarkan hasil perhitungan SPSS V.25 pada periode dua tahun sebelum dengan tahun pelaksanaan proses merger serta akuisisi didapat nilai $t$ hitung $<$ t tabel $(1,664<2,201)$ dan tingkat signifikan $>0,05(0,130>0,05)$, periode dua tahun sebelum dengan setahun pasca proses merger serta akuisisi diperoleh nilai thitung $<$ t tabel $(0,074<2,201)$ dan tingkat signifikan $>0,05$ $(0,943>0,05)$, periode dua tahun sebelum dengan dua tahun pasca proses merger serta akuisisi diperoleh nilai $t$ hitung $<\mathrm{t}$ tabel $(-0,216<-2,201)$ dan tingkat signifikan $>0,05(0,833>0,05)$, periode dua tahun sebelum dengan tiga tahun pasca proses merger serta akuisisi diperoleh nilai $\mathrm{t}$ hitung $<\mathrm{t}$ tabel $(-0,769<2,201)$ dan tingkat signifikan $>0,05(0,461>0,05)$, periode dua tahun sebelum dengan periode empat tahun pasca merger serta akuisisi diperoleh nilai $t$ hitung $<\mathrm{t}$ tabel $(-0,610<-2,201)$ dan tingkat signifikan>0,05 $(0,557>0,05)$, periode setahun sebelum dengan 
tahun pelaksanaan proses merger serta akuisisi diperoleh nilai $t$ hitung $<\mathrm{t}$ tabel $(1,804<2,201)$ dan tingkat signifikan $>0,05(0,105>0,05)$, pada periode setahun sebelum dengan setahun pasca proses merger serta akuisisi diperoleh nilai $t$ hitung $<\mathrm{t}$ tabel $(1,261<2,201)$ dan tingkat signifikan $>0,05(0,239>0,05)$, pada setahun sebelum dengan dua tahun pasa proses merger serta akuisisi diperoleh nilai $\mathrm{t}$ hitung $<\mathrm{t}$ tabel $(1,334<2,201)$ dan tingkat signifikan $>0,05(0,215$ $>0,05)$, pada periode setahun sebelum dengan tiga tahun pasca merger serta akuisisi diperoleh nilai $\mathrm{t}$ hitung $<\mathrm{t}$ tabel $(0,617<2,201)$ dan tingkat signifikan $>0,05(0,553>0,05)$, periode setahun sebelum dengan empat tahun pasca proses merger serta akuisisi diperoleh nilai $\mathrm{t}$ hitung $<\mathrm{t}$ tabel $(1,031<2,201)$ dan tingkat signifikan $>0,05(0,329>0,05)$ sehingga dari uraian hasil riset disimpulkan bahwa Ho dapat diterima sementara Ha ditolak, yang dapat diartikan ditemukan kondisi yang sama antara capaian finansial antara sebelum proses penggabungan usaha dengan periodepasca proses penggabungan usaha berdasarkan rasio keuangan Price Earnings Ratio (PER).

Price Earnings Ratio (PER) yang dilakukan pada entitas (perusahaan) yang melakukan proses penggabungan usaha sehingga dapat diukur capaian kepemilikan saham pada entitas, yang mempunyai tujuan supaya memperoleh keuntungan yang masimal pada saham yang ada, semakin tumbuh besarnya perusahaan dan juga semakinbertambahnya nilai perusahaan (Oktavia, 2016). Tujuan tersebut tidak tercapai dikarenakan perusahaan tidak mengalami kenaikan laba yang cukup besar sehingga tidak berdampak terhadap harga saham entitas (perusahaan) tersebut. Hal ini didukung oleh teori keagenan dimana pengelola manajemen perusahaan memiliki keleluasaan memaksimalkan laba sehingga dapat mengarah pada proses memaksimalkan kepentingan pengelola sendiri dan dapat terjadinya masalah keagenan dikarenakan kebijakan yang diambil memiliki perubahan tujuan sehingga permasalahan keagenan internal tersebut dapat dijadikan suatu langkah kebijakan perusahaan dengan mengadakan penggabungan usaha (merger dan akuisisi) yang dilaksanakan tidak berdampak besar bagi perusahaan. Hal ini didukung hasil penelitian yang dilakukan oleh Sumarah (2018) menunjukan tidak adanya perbedaan pada periode antara kondisi semula dengan pasca proses merger serta akuisisi pada Price Earning Ratio. Hal tersebut diakibatkan terjadinya peningkatan keuntungan, akan tetapi peningkatan tersebut tidaklah signifikan namun tidak berpengaruh apapun bagi entitas, begitu juga nilai perusahaan setali tiga uang dengan pernyataan diatas dampak yang timbul terkait dengan nilai perusahaan (image) serta harga saham beredar. Akan tetapi dalam riset oleh (Laiman \& Hatane, 2017) justru tidak sesuai dimana dalam penelitiannya menyatakan bahwa perusahaan sektor non keuangan memiliki perbedaan signifikan pada periode semula dengan pasca pelaksanaan penggabungan usaha terhadap kinerja keuangan Price Earning Ratio.

\section{SIMPULAN}

Dari uraian diatas dan hasil analisis data serta bahsan yang telah diuraikan dapat disimpulkan antara lain: Terdapat ketidaksamaan hasil kinerja keuangan antara dua tahun sebelum dengan dua tahun pasca proses merger serta akuisisi, pada periode setahun sebelum dengan tiga tahun pasca proses merger dengan akuisisi, berdasarkan rasio keuangan dengan indikator current ratio (CR) pada perusahaan akuisisi yang listed di BEI periode 2013-2019. Terdapat ketidaksamaan hasil capaian finansial pada periode pengamatan antara dua tahun sebelum dan tiga tahun sesudah pelaksanaan proses merger dan akuisisi,selanjutnya pada periode dua tahun sebelum dan empat tahun setelah pelaksanaan proses merger dan akuisisi, pada periode setahun sebelum dan tahun pelaksanaan proses merger dan akuisisi, periode setahun sebelum dan dua tahun setelah proses merger dan akuisisi, periode setahun sebelum dengan tiga tahun pasca proses merger serta akuisisi, pada periode setahun sebelum dan empat tahun setelah proses merger dan akuisisi, berdasarkan rasio keuangan dengan indikator DAR 
pada perusahaan pengakuisisi yang listed di BEI periode 2013-2019. Terdapat perbedaan hasil capaian finansial antara pada periode dua tahun sebelum dengan tahun pelaksanaan merger serta akuisisi, pada periode dua tahun sebelum dengan setahun pasca merger serta akuisisi, periode dua tahun sebelum dengan dua tahun pasca merger dan akuisisi, periode dua tahun sebelum dengan empat tahun pasca proses merger serta akuisisi, pada periode setahun sebelum dengan tahun pelaksanaan merger serta akuisisi, pada periode setahun sebelum dengan setahun pasca merger serta akuisisi, periode setahun sebelum dengan dua tahun pasca merger serta akuisisi, periode setahun sebelum dengan empat tahun pasca merger dan akuisisi berdasarkan rasio keuangan dengan indikator TATO pada entitas pengakuisisi yang listed di BEI periode 2013-2019. Capaian Fiannsial antara periode sebelum dengan setelah pelaksaan proses penggabungan usaha ternyata tidak ditemukan perbedaan signifikan berdasarkan ukuran finansial Net Profit Margin (NPM) bagi entitas pengakuisisi yang listed di BEI periode 2013-2019. Terdapat perbedaan hasil kinerja keuangan periode antara dua tahun sebelum dengan setahun pasca pelaksanaan proses merger serta akuisisi,periode dua tahun sebelum dengan dua tahun pasca proses merger serta akuisisi, periode setahun sebelum dengan setahun pasca proses merger dengan akuisisi,periode setahun sebelum dengan dua tahun pasca proses merger dan akuisisi yang didasarkan pada rasio keuangan dengan indikator yakni ROA pada perusahaan pengakuisisi yang listed di BEI periode 2013-2019. Terdapat perbedaan kinerja keuangan pada periode antara dua tahun sebelum dengan tahun pelaksanaan proses merger serta akuisisi, periode dua tahun sebelum dengan setahun pasca proses merger serta akuisisi yang berasal dari rasio keuangan dengan indicator yakni $R O E$ pada perusahaan pengakuisisi yang listed di BEI periode 2013-2019. Tidak ditemukan adanya ketidaksaan capaian finansial pada periode antara sebelum dengan pasca proses merger Serta akuisisi berdasarkan ukuran fiansial dengan indikator EPS pada perusahaan pengakuisisi yang terdaftar di BEI periode 2013-2019. Tidak ditemukan adanya perbedaan capaian finansial pada periode antara sebelum dengan pasca proses merger serta akuisisi yang berasal dari ukuran finansial dengan menggunakan indikator PER pada entitas pengakuisisi yang listed di BEI periode 2013-2019.

\section{DAFTAR PUSTAKA}

Cahyarini, I., \& Pustikaningsih, A. (2017). Analisis Perbedaan Kinerja Keuangan Perusahaan Sebelum Dan Sesudah Merger Dan Akuisisi (Studi Empiris Pada Perusahaan Merger Dan Pengakuisisi Yang Terdaftar Di Bursa Efek Indonesia Periode 2012-2014). Jurnal Profita: Kajian Ilmu Akuntansi, 5(7).

Esterlina, P. (2017). Analisis kinerja keuangan perusahaan sebelum dan sesudah merger dan akuisisi (Doctoral dissertation, Universitas Brawijaya).

Fitriasari, F. (2016). Analisis Perbandingan Kinerja Keuangan Perusahaan Sebelum Dan Sesudah Merger Dan Akuisisi Terhadap Manajemen Entrenchment (Studi Perusahaan Yang Melakukan Merger Dan Akuisisi yang Terdaftar Di BEI Periode 2011-2013) (Doctoral dissertation, Universitas Muhammadiyah Sidoarjo).

Ghozali, I. (2018). Aplikasi analisis multivariate dengan program IBM SPSS 25. Semarang: Badan Penerbit Universitas Diponegoro.

Gustina, I. (2017). Analisis Kinerja Keuangan Sebelum dan Sesudah Merger dan Akuisisi pada Perusahaan yang Go Public yang Terdaftar di BEI. Jurnal Akuntansi Dan Keuangan, 6(1).

Imannuel, F. L. (2020). Analisis Kinerja Operasional Perusahaan Sebelum Dan Setelah Merger Atau Akuisisi (Studi Kasus Pada Perusahaan Di Indonesia Terdaftar Di 
Bursa Efek Indonesia Periode 2015-2019). Naskah Publikasi Program Studi Akuntansi.

Khasanah, Nur. "Analisis Kinerja Keuangan Sebelum Dan Sesudah Merger Dan Akuisisi (Studi Kasus Pada Perusahaan Non Bank Yang Terdaftar Di Bursa Efek Indonesia Periode 2013-2015)." PhD diss., Universitas Pasir Pengaraian, 2017.

Kusumaningtyas, R., \& Handayani, S. R. (2018). Analisis Rasio untuk mengukur kinerja keuangan sebelum dan sesudah melakukan akuisisi (Studi Kasus pada PT Alam Sutera Realty Tbk periode 2008-2016). Jurnal Administrasi Bisnis, 65(1), 74-82.

Laiman, L., \& Hatane, S. E. (2017). Analisis dampak merger dan akuisisi terhadap kinerja keuangan pada perusahaan non keuangan yang terdaftar di Bursa Efek Indonesia periode tahun 2007-2014. Business Accounting Review, 5(2), 517-528.

Moctar, N. B., \& Xiaofang, C. H. E. N. (2014). The Impact of Mergers and Acquisition on the financial performance of West African Banks: A case study of some selected commercial banks. International Journal of Education and Research, 2(1), 1-10.

Oktavia, D. A.(2016). Analisis Pengaruh Merger Dan Akuisisi Terhadap Kinerja Keuangan Bank Pada Bank Umum Swasta Nasional Devisa Di Indonesia Periode 2005-2008 (Bachelor's thesis, Jakarta: Fakultas Ekonomi dan Bisnis UIN Syarif Hidayatullah Jakarta).

Sajow, Y. E., Manoppo, W. S., \& Keles, D. (2017). Analisis Perbandingan Kinerja Keuangan Sebelum Dan Sesudah Merger (Studi Kasus Pada PT. Xl Axiata Tbk). JURNAL ADMINISTRASI BISNIS (JAB), 5(002).

Serenade, V., Rahmawati, C. H. T., \& Dewi, I. J. (2019, December). Analisis Perbandingan Kinerja Keuangan Perusahaan Sebelum dan Sesudah Akuisisi. In Prosiding Seminar Nasional Multidisiplin Ilmu (Vol. 1, No. 2, pp. 268-276).

Sudana, I. M. (2015). Teori dan Praktik Manajemen Keuangan Perusahaan. Jakarta: Erlangga.

Sudarsono, H. (2009). Dampak krisis keuangan global terhadap perbankan di indonesia: perbandingan antara bank konvensional dan bank syariah. La_Riba, 3(1), 12-23.

Sumarah, D. R., \& Priantinah, D. (2018). Analisis Kinerja Keuangan, Nilai Perusahaan, Harga Saham Perusahaan Melakukan Merger Akuisisi Tahun 2010-2014. Jurnal Profita: Kajian Ilmu Akuntansi, 6(8).

Tarigan, J., Claresta, A., \& Hatane, S. E. (2018). Analysis Of Merger \& Acquisition Motives In Indonesian Listed Companies Through Financial Performance Perspective. Kinerja, 22(1), 95-112. 